\title{
Interactive comment on "Pyrocumulonimbus
}

\section{Events over British Columbia in 2017: The}

\section{Long-term Transport and Radiative Impacts of}

Smoke Aerosols in the Stratosphere" by

Sampa Das et al.

Anonymous Referee \#2

Received and published: 23 February 2021

The comment was uploaded in the form of a supplement:

https://acp.copernicus.org/preprints/acp-2020-1240/acp-2020-1240-RC2-

supplement.pdf

Interactive comment on Atmos. Chem. Phys. Discuss., https://doi.org/10.5194/acp-2020-1240, 